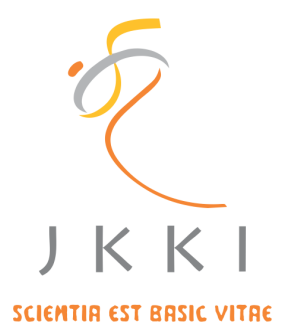

Jurnal Kedokteran dan Kesehatan Indonesia

\author{
Indonesian Journal of Medicine and Health
}

Journal homepage: https://journal.uii.ac.id/JKKI

\title{
Effectiveness of iron supplementation for children with iron deficiency anemia: Study in Purbalingga, Central Java
}

Tien Budi Febriani*1, Emi Azmi Choironi ${ }^{1}$, Latifah Hanum ${ }^{2}$

${ }^{1}$ Department of paediatrics, Faculty of Medicine, Universitas Islam Indonesia, Yogyakarta, Indonesia

${ }^{2}$ Paediatrician in Purbalingga District Hospital, Purbalingga, Central Java, Indonesia

Original Article

\begin{tabular}{l}
\hline \\
\hline ART I C L E I N F O \\
\hline Keywords: \\
anaemia, \\
iron deficiency anaemia, \\
children below 5 years old, \\
iron supplementation, \\
haemoglobin levels \\
*Corresponding author: \\
tienbudifebriani@gmail.com \\
\hline DOI: 10.20885/JKKI.Vol11.Iss1.art11 \\
History: \\
Received: November 15, 2019 \\
Accepted: April 14, 2020 \\
Online: April 30, 2020 \\
\hline Copyrigh @2020 Authors.
\end{tabular}

Copyright @2020 Authors. This is an open access article distributed under the terms of the Creative Commons Attribution-NonCommercial $\quad 4.0$ International Licence (http:// creativecommons.org/licences/ by-nc/4.0/).

\section{ABSTRACT}

Background: Iron Deficiency Anaemia (IDA) is one of major factors for human health, especially young children. Iron supplementation can indicate a good response in haemoglobin concentration.

Objective: This study is to observe prevalence of anaemia and effectiveness of iron supplementation for children in Purbalingga district, Central Java.

Methods: This study was a quasi-experimental study by measuring haemoglobin concentration before (pre) and after (post) treatment. Its participants were determined by a purposive sampling method. 64 children (less than 5 years old) were included in criteria of anaemia. Their blood samples were collected before the treatment to measure SI (Serum Iron) and TIBC (Total Iron Binding Capacity). Administering $4 \mathrm{mg}$ of iron per kg of body weight per day was conducted for a month. Data of participants such as age, nutritional status, socio-demographic, and medical history were also collected. A paired t-test was used to analyse mean differences of haemoglobin levels before and after treatment.

Results: Among the 64 children with anaemia, 98.4\% indicated Iron Deficiency (ID) with $59.4 \%$ of them indicating IDA based on level of SI and TIBC. Anaemia has more prevalence in group of $6-<12$ months of age. There was a statistically significant increase of haemoglobin level with a mean difference of $1.52 \mathrm{~g} / \mathrm{dL}$ between the pre and post treatment $(\mathrm{p}=0.000)$.

Conclusion: The prevalence of IDA in children (less than 5 years old) in Purbalingga District Hospital was 59.4\%. Adequately oral iron supplementation for a month indicated a statistically significant increase of haemoglobin levels.

Latar Belakang: Anemia Defisiensi Besi (ADB) adalah salah satu faktor utama dalam kesehatan manusia, terutama anak-anak. Suplementasi zat besi dapat menunjukkan respon yang baik terhadap konsentrasi hemoglobin.

Tujuan: Penelitian ini bertujuan untuk mengobservasi prevalensi anemia dan efektivitas pemberian zat besi untuk anak-anak di kabupaten Purbalingga, Jawa Tengah.

Metode: Penelitian ini adalah penelitian quasi-eksperimen yang mengukur jumlah konsentrasi hemoglobin sebelum (pra) dan setelah (pasca) perawatan. Para peserta yang menjadi subyek dalam penelitian ini ditentukan dengan metode purposive sampling. 64 anak-anak (di bawah 5 tahun) termasuk dalam kriteria anemia. Sampel darah mereka dikumpulkan sebelum perawatan dilaksanakan untuk mengukur Serum Iron (SI) dan Total Iron Binding Capacity (TIBC). Pemberian $4 \mathrm{mg}$ zat besi per $\mathrm{kg}$ berat badan per hari dilakukan selama sebulan. Data peserta dalam penelitian ini seperti usia, status gizi, sosio-demografis, dan riwayat medis juga dikumpulkan. Uji t-berpasangan digunakan untuk menganalisisa perbedaan rata-rata kadar 
hemoglobin sebelum dan sesudah pengobatan.

Hasil: Diantara 64 anak dengan anemia, 98.4\% menunjukkan kekurangan zat besi dan 59.4\% dari mereka menunjukkan ADB berdasarkan tingkat SI dan TIBC. Anemia memiliki prevalensi lebih banyak pada kelompok usia 6-<12 bulan. Ada peningkatan kadar hemoglobin yang signifikan secara statistik dengan perbedaan rata-rata $1.52 \mathrm{~g} / \mathrm{dL}$ ketika sebelum dan sesudah pengobatan $(p=0.000)$.

Kesimpulan: Prevalensi $A D B$ pada anak-anak (di bawah 5 tahun) di Rumah Sakit Kecamatan Purbalingga adalah 59.4\%. Suplementasi zat besi secara oral yang cukup selama sebulan mengindikasikan peningkatan kadar hemoglobin yang signifikan secara statistik.

\section{INTRODUCTION}

Anaemia is one of major problems in public health affecting for both developing and developed countries. It is estimated that almost $30 \%$ of world's population is anaemic, and half of them can indicate Iron Deficiency Anaemia. Prevalence of IDA in Indonesia is still high, especially in pregnant women, children less than five years old, children in school age and low-income workers. ${ }^{1}$ Factors, which can lead to IDA in children, are lack of iron intake, increasing need, infections, and others. Indonesian Demographic and Health Survey in 2012 reported that incidence of IDA was $48.1 \%$ in a group below 5 years old and $47.3 \%$ in a group of school age. ${ }^{2}$ Moreover, Basic Health Research (called RISKESDAS in Indonesia) in 2018 showed that $48.9 \%$ of pregnant women in Indonesia suffered the IDA, that could contribute to high incidence of anaemia in infants and children. ${ }^{3}$ It was also reported that 37\% infants ageing 4-5 months in West Java, Central Java, and East Java had haemoglobin level of $<10 \mathrm{~g} / \mathrm{dL}$, and $71 \%$ infants showed haemoglobin level of $<11 \mathrm{~g} / \mathrm{dL}^{4}{ }^{4}$

IDA refers to lack of iron stores that contribute to decrease of physiological capability of oxygen binding. This condition may be resulted from a decrease of iron absorption. ${ }^{5}$ Deficiency of iron can affect mental and intelligent development. Erythrocytes play an important role to transfer oxygen to all parts of the body especially brain; therefore, anaemic children can suffer less fulfilled oxygen in their brain. ${ }^{6,7}$ Consequently, anaemic children can experience poor learning capability, low attention span, and low IQ test. ${ }^{8}$ Iron is also essential nutrient for development of the brain and immune system. Risks of infection can increase in IDA as a result of impaired function of immune system. ${ }^{9}$

A previous study in a rural in Central Java reported that daily oral supplementation of 10 mg ferrous sulphate per kilogram of body weight per day for 3 months can effectively increase haemoglobin $(\mathrm{Hb})$ concentration and improve learning achievement among school-children. ${ }^{10}$ Muhilal et al. reported that a pilot program of daily oral iron supplementation of $3 \mathrm{mg} / \mathrm{kg}$ of body weight for 2.5 months could reduce $24 \%$ anaemia prevalence in pre-school children and $25 \%$ in school-children, respectively. ${ }^{11}$ Indonesian Paediatric Society (IPS) recommends 4-6 mg of iron per kilogram of body weight per day to treat the IDA and to increase $1-2 \mathrm{mg} / \mathrm{dl}$ level of haemoglobin. ${ }^{12}$ Therefore, a study on effectiveness of iron supplementation to increase haemoglobin concentration for children below 5 years old in Purbalingga need to be conducted.

\section{METHODS}

\section{Study design and Subjects}

This study used a quasi-experimental design located in Purbalingga District Hospital. Samples in this study were 64 children with anaemia below 5 years old, who were enrolled (between November 2016 and January 2017) and recruited from Paediatric Unit of Purbalingga District Hospital after getting an ethical agreement letter. All the participants were included in inclusion criteria of anaemia based on WHO criteria with haemoglobin level of $<11.5 \mathrm{~g} / \mathrm{dL}$. They also had clinically severe diseases (severe infection, renal or autoimmune disease and malignancy) and other haematological disorders such as thalassemia, haemophilia, blood malignancy based on clinical manifestation (liver or spleen enlargement, node lymph enlargement, history of familial blood coagulation disorder, hamarthrosis) or supporting laboratory results (leucocytosis or leukopenia with anaemia or/ and thrombocytopenia) were excluded. 
Measurement of haemoglobin concentration was conducted before and after treatment. Supplementation of 4-6 mg of elemental iron per kilogram of body weight per day was administered to each participant for a month. A daily monitoring questionnaire filled by parents was purposed to check subject's compliance during the treatment. A post-treatment evaluation was organized after the one-month treatment was finished. A nutritional status was determined based on growth chart curve, and body weight to length was based on z-score curve. Data was collected by using forms of study.

Socio-demographic data, medical and dietary history were obtained by interviewing participants' parents or caretakers by using a structured questionnaire that was conducted by a paediatrician. The paediatrician had no information about the SI and TIBC data.

\section{Blood samples analysis}

Laboratory observation in this study included complete blood count (Hb), SI and TIBC. Complete blood count was examined by using 2 cc EDTA blood, and SI and TIBC was examined by using specimen blood serum. Laboratory examination and measurement for the complete blood count, SI and TIBC applied a standard used in a private laboratory in Purbalingga.

Blood samples were collected to measure the SI and TIBC. $5 \mathrm{ml}$ venous blood sample was drawn from each participant into plain tubes without an added anticoagulant. The blood sample was drawn before an intervention.

\section{Statistical analysis}

Data were processed an analysed statistically to compare mean differences between the pre and post treatment of haemoglobin concentration. Mean differences of SI and TIBC between ID, IDA, and non-ID group were compared by using student's t-test. Chi square test was used to determine significant differences of prevalence between ID, IDA and non-ID group in nominal data (sex, level of parental education and economy, history of iron supplementation, nutritional status). Differences of mean and prevalence among the groups were considered statistically significant if $\mathrm{p}<0.05$.

\section{RESULTS}

64 children below five years old were enrolled in this study. Age of the participants ranged from 2-58 months, and their mean of age was 16.1 months. Characteristics of them were portrayed in Table 1.

Table 1. Participant Characteristics

\begin{tabular}{lccc}
\hline \multicolumn{1}{c}{ Characteristics } & Mean & N & \% \\
\hline Age (month) & 16.1 & & \\
Hb level (pre-treatment) & $9.88(7.0-10.9)$ & & \\
Age group (month) & & & \\
$0-<6$ & & 6 & 9.4 \\
$6-<12$ & 24 & 37.5 \\
$12-<24$ & 23 & 35.9 \\
$24-<60$ & 11 & 17.2 \\
Sex & & \\
Male & & 36 & 56.3 \\
Female & 28 & 43.8 \\
Nutritional status & & \\
Normoweight & 13 & 81.3 \\
Underweight & & 2 & 12.5 \\
Severely underweight & & 1 & 6.3 \\
\hline
\end{tabular}


Percentage of anaemia was highest in age $6-<12$ months compared to other groups based on their age. Families with low-middle economy and educational status had the highest prevalence among the participants, but most participants were normoweight. According to the level of iron status, $98.4 \%$ anaemic children indicated iron deficiency; however, only $59.4 \%$ of the participants suffered IDA. Then $40.6 \%$ of them was still in iron deficiency phase, either iron depletion or iron deficiency erythropoietin phase. Table. 2 illustrates levels of iron deficiency based on iron status. It was also found that serum iron and transferrin saturation between ID and IDA group had significant mean differences ( $\mathrm{p}<0.05$, student's t test, Table 3). Administering 4-6 mg of oral elemental iron per kilogram of body weight per day for a month showed a statistically significant increase of haemoglobin levels, with mean differences of $1.68(\mathrm{p}<0.008$, Table 4$)$.

Table 2. Classification of anaemia based on iron status

\begin{tabular}{lc}
\hline \multicolumn{1}{c}{ Classification of Anaemia } & $\mathbf{N}(\%)$ \\
\hline Iron depletion/storage iron deficiency & $18(28.1)$ \\
Iron deficient erythropoietin & $7(10.9)$ \\
Iron deficiency anaemia & $38(59.4)$ \\
Iron overload & $1(1.6)$ \\
Total & $64(100.0)$ \\
\hline
\end{tabular}

Table 3. Mean comparison of serum iron, TIBC, ID and IDA

\begin{tabular}{lccc}
\hline \multicolumn{1}{c}{ Iron Status } & IDA (SD) & ID (SD) & p \\
\hline Serum iron (ug/dL) & $22.57(9.76)$ & $72.69(2.69)$ & 0.000 \\
TIBC (ug/dL) & $345.44(71.52)$ & $317.19(63.02)$ & 0.109 \\
\hline $\mathrm{p}<0.05$ & & &
\end{tabular}

Tabel 4. Mean difference of haemoglobin before and after an month treatment

\begin{tabular}{lccc}
\hline & Pre treatment & Post treatment & p \\
\hline Mean Hb level $(\mathrm{g} / \mathrm{dL})$ & 9.88 & 11.56 & 0.008 \\
\hline
\end{tabular}

\section{DISCUSSION}

Based on analysis of this study, the mean difference of haemoglobin before and after the oral iron treatment indicated a significance difference. This is consistent with an assumption suggesting that adequately oral iron treatment for a month can show a statistically significant increase of haemoglobin levels. Global trend of IDA prevalence has declined since the last decades; it is still a substantial problem in developing countries, such as Indonesia. Widjaja et al. reported that prevalence of anaemia in Malinau, East Kalimantan was 53.9\%, and its IDA prevalence based on Mentzer index in age groups of 6-59 months, 5-11.9 years old and $12-18$ years old was $26.5 \%, 13.6 \%$, and $13.2 \%$, respectively. ${ }^{13}$ However, in this study, the IDA prevalence among all anaemia cases based on iron status was $59.4 \%$. This is in accordance to a report by Widiaskara et al. that prevalence of IDA was $65.3 \%$ among hospitalized children due to other diagnoses in District Hospital of Wangaya, Denpasar. ${ }^{14}$

An recent study also found that IDA was more common in age of $6-<12$ months (37.5\%). This result is supported by a previous study reporting that anaemia in children ageing 6-11 months was $37.3 \% .{ }^{14}$ Results of Household 
Health Survey (SKRT) in 2014 also pointed that prevalence of IDA in infants ageing 6-12 months was the highest (64.8\%), compared to the infant ageing 0-6 months (61.3\%) and children below five years old $(48,1 \%) \cdot{ }^{15}$ In our study, the SI level was significantly lower in the IDA group than in the ID group. However, there was no significantly difference of TIBC between the two groups. It might because most participants in this study were patients with illness or post illness. Therefore, aetiology of ID was not only IDA but also combination of anaemia with chronic diseases.

Based on this study, anaemia with chronic diseases was excluded. Anaemia with chronic diseases may be accompanied by IDA as a result of decrease of iron mobilization activity from reticuloendothelial system into plasma activity, whereas transferrin saturation may decrease due to transferrin degradation. Iron is bound to transferrin in the plasma. TIBC is a direct measure of transferrin level, so anaemia with chronic diseases may indicate a decrease or normal TIBC level, a distinct condition except those in the IDA. Serum ferritin level is also useful to distinguish between those two types of anaemia. In IDA, the level of serum ferritin is low contrasting to the serum ferritin in anaemia with chronic diseases. ${ }^{16}$ A limitation of our study is unable to determine the levels of serum ferritin because of limited cost of this study.

Nevertheless, our study reported a statistically significant increase of haemoglobin levels after treatment. This result is in accordance to high prevalence of iron deficiency in this region with more than 95\%. An increase of haemoglobin level 1-2 $\mathrm{g} / \mathrm{dL}$ within one month following adequate iron therapy is one of diagnostic tools in area with minimum facilities to measure iron status. ${ }^{12}$

There is three phases of iron deficiency. The first phase is iron depletion or storage iron deficiency; the second phase is iron deficient erythropoietin or iron limited erythropoiesis; and the final phase is IDA. The subsequent phases consist of decrease of iron storage, decrease of serum ferritin, decrease of iron serum with increase of serum transferrin, increase of Red cell Distribution Width (RDW), decrease of Mean Corpuscular Volume (MCV), and decrease of haemoglobin level. ${ }^{17}$

Socio-economic and parental education as well as acute and chronic infections are widely known as important factors in IDA. Paternal schooling is closely associated to family income. Lower income family can relate to IDA due to inability to get iron-rich foods, poor sanitation leading to infection, and misinformation of iron supplementation. ${ }^{18}$ In this study, more than half participants were from family with low and middle income and with low and middle parental education level. Further investigation is necessary to explore relationship among factors contributing to the IDA.

Young children are more susceptible to iron deficiency because of rapid growth that requires high iron. On the contrary, lack of iron content in complementary foods and frequent episodes of infection. Breast milk contains relatively low levels of iron but it is simply absorbable and sufficient for infants until six months of age. Therefore, extra iron is required from six months to future age, either from complementary food or from some supplements. Unfortunately, common complementary food given to infants ageing 6 months in Indonesia are bananas or rice flour mixed with breast milk. This food provides many calories but contains low bioavailable iron, low protein and zinc, and high phytate. The amount of iron provided by a banana is 0.3 mg of iron, whereas $28 \mathrm{~g}$ of rice flour contains only $0.1 \mathrm{mg}$ of iron. This condition is insufficient based on Recommended Daily Intake (RDI) stating that children ageing 6-12 months need $11 \mathrm{mg}$ per day. ${ }^{19}$

This study was conducted as well as possible, but it still has some limitations. The guideline for the IDA is administering 4-6 mg of orally elemental iron per kilogram of body weight per day for one until two months. Daily iron supplementation is a preventive strategy that can be implemented at a population level.

Almost $50 \%$ of pregnant women in 
Indonesia suffer IDA that contributes to the high incidence of anaemia in infants and children. To keep public health, Indonesian Paediatrics Society has recommended giving daily iron supplementation for infants and children ageing 6-23 month. Iron is a micronutrient that the body needs to make haemoglobin.

If the clinicians found a clinical manifestation of anaemia, supplementation of iron needs to be prescribed. Then the clinicians should check a response treatment after 1 until 1.5 months. If there is no response (below $1.0 \mathrm{~g} /$ $\mathrm{dL}$ of increase in haemoglobin or $<3$ unit of increase in haematocrit), despite what appears to be good compliance, the clinician should determine the serum ferritin concentration and consider other causes of anaemia. If there is a response resulting from the iron supplementation, it should be continued until the haemoglobin concentration becomes 12.0 $\mathrm{g} / \mathrm{dL}$. And after which iron can be decreased to a maintenance level of about $30 \mathrm{mg}$ of iron per day for 4 months and then discontinued. ${ }^{15}$

Alteration of diet may retard the development of the IDA and avoid the need for supplemental iron in children. Further investigation is necessary to explore relationships among the factors contributing to the IDA in children.

\section{CONCLUSION}

This study found that Purbalingga had high prevalence of iron deficiency with more than 95\%. Administering 4-6 mg of orally elemental iron per kilogram of body weight per day for a month could make the haemoglobin levels increase.

\section{CONFLICT OF INTEREST}

There is no conflict of interest in this study.

\section{ACKNOWLEDGEMENT}

The researchers thank to who participated in this study.

\section{REFERENCES}

1. Kementrian Kesehatan RI. Profil Kesehatan Indonesia Tahun 2013. Jakarta: Sek- retariat Jendral Departement Kesehatan. 2014.

2. Statistic Indonesia (Badan Pusat Statistik-BPS), National Population and Family Planning Board (BKKBN, Kementerian Kesehatan (Kemenkes-MOH)) and ICF International. Indonesia demographic and health survey 2012. Jakarta: BPS, BKKBN, Kemenkes, and ICF International. 2013.

3. Indonesia Ministry of Health General Secretariat. Indonesia health profile 2018. Jakarta: Ministry of Health RI. 2018.

4. De Pee S, Bloem MW, Sari M, Kiess L, Yip $\mathrm{R}$, Kosen $\mathrm{S}$. The high prevalence of low hemoglobin concentration among Indonesian infants aged 3-5 months is related to maternal anemia. The Journal of Nutrition. 2002;132(8):2215-21.

5. Baker RD, Greer FR, Bhatia JJS, Abrams SA, Daniels SR, Schneider MB, et al. Clinical report - diagnosis and prevention of iron deficiency and iron-deficiency anemia in infants and young children (0-3 years of age). Pediatrics. 2010;126(5):1040-50.

6. Metallinos-Katsaras E, Valassi-Adam E, Dewey KG, Lönnerdal B, Stamoulakatou A, Pollitt E. Effect of iron supplementation on cognition in Greek preschoolers. European Journal of Clinical Nutrition. 2004;58(11):1532-42.

7. Soewondo S. The effect of iron deficiency and mental stimulation on Indonesian children's cognitive performance and development. Kobe Journal of Medical Sciences. 1995;41(1-2):1-17.

8. Kordas K, Lopez P, Rosado JL, García Vargas G, Alatorre Rico J, Ronquillo D, et al. Blood lead, anemia, and short stature are independently associated with cognitive performance in Mexican school children. The Journal of Nutrition. 2004;134(2):363-71.

9. Cherayil BJ. Iron and immunity: Immunological consequences of iron deficiency and overload. Archivum Immunologiae et Therapiae Experimentalis. 2010;58(6):407-15.

10. Soemantri AG, Pollitt E, Kim I. Iron deficiency anemia and educational achievement. American Journal of Clinical Nutrition. 1985;42(6):1221-8. 
11. Muhilal, Suharno D, Saidin S, Permaesih D, Satibi I. Iron supplementation pilot programme. Gizi Indonesia. 1985;30-4.

12. Pudjiadi AH, Hegar B, Handryastuti S, Idris NS, Gandaputra EP, Harmoniati ED, editors. Anemia defisiensi besi. In: pedoman pelayanan medis ikatan dokter anak Indonesia. Jakarta: IDAI; 2009. p. 10-3.

13. Riyanto Widjaja I, Firyanto Widjaja F, Alim Santoso L, Wonggokusuma, E, Oktaviati $\mathrm{O}$. Anemia among children and adolescents in a rural area. Paediatrica Indonesiana. 2013;54(2):88-93.

14. Widiaskara I, Pramitha P, Suryawan IWB, Ugrasena I. Gambaran hematologi anemia defisiensi besi pada anak. Sari Pediatri. 2016;13(5):362.

15. WHO. Guideline daily iron supplementation in infants and children. Geneva: World Health Organization. 2016;44.

16. Muhammad A, Sianipar O. Determination of iron deficiency in chronic disease anemia by the role of sTfR-F index. Indonesian Journal of Clinical Pathology and Medical Laboratory. 2005;12(1):9-15.

17. Permono B, Sutaryo UIDG, Windiastuti E, Abdulsalam M. Buku ajar hematologi-onkologi anak. Jakarta: Badan Penerbit Ikatan Dokter Anak Indonesia; 2017.

18. Cotta RMM, Fabiana de Cássia Carvalho Oliveira, Magalhães KA, Ribeiro AQ Sant'Ana LF da R, Priore SE, et al. Social and biological determinants of iron deficiency anemia. Cadernos de Saúde Pública. 2011;27(suppl 2):s309-20.

19. Sjarif DR, Yuliarti K, Lestari ED, Sidiartha IGL, Nasar SS, Mexitalia M. Rekomendasi praktik pemberian makan berbasis bukti pada bayi dan balita di Indonesia untuk mencegah malnutrisi. Jakarta: Ikatan Dokter Anak Indonesia. 2015; 